\title{
Testing of laboratory samples of microbiological preparations based on promising producer strains for the control of apple scab
}

\author{
Lyubov Maslienko ${ }^{1 *}$, and Galina Yakuba $^{2}$ \\ ${ }^{1}$ Federal State Budgetary Scientific Institution «Federal scientific center «V.S. Pustovoit All-Russian \\ Research Institute of Oil crops» (FSBSI «FSC «ARRIOC»), 17 str. Filatova, Krasnodar, 350038, \\ Russia \\ ${ }^{2}$ Federal State Budget Scientific Institution «North Caucasian Federal Scientific Center of \\ Horticulture, Viticulture, Wine-making», 39 str. 40 Let Pobedy, Krasnodar, 350901, Russia
}

\begin{abstract}
To prevent phytosanitary destabilization in apple agrocenoses, it is necessary to include ecologically safe microbiological preparations in the protection systems. In the Krasnodar region in 2016 and 2019 in the field, laboratory samples of microbiological preparations were tested in the formulation "wettable powder" from the collection of the laboratory of the biological method of the FGBNU VNIIMK against Venturia inaequalis (Cooke) G. Winter. Of the 9 laboratory samples tested in 2016, the highest efficiency, approaching the effectiveness of a chemical fungicide, was shown by samples based on fungal producer strains: RK-1, XK-1 and T-2 76.9-92.5\%. In 2019, all variants (in the amount of 4) using laboratory samples of microbiological preparations were more effective in comparison with the active substance of chemical origin. The best scab control was provided by a laboratory sample of a three-component mixed preparation based on two fungal and one bacterial producer strain RK-1 + XK-1 + B-12 - 83.0-84.9\%. The isolated samples are promising for research on the creation of microbiological preparations against apple scab.
\end{abstract}

\section{Introduction}

In apple tree plantations, both in Russia and abroad, the most dangerous disease is scab Venturia inaequalis (Cooke) G. Winter. Climate warming, and in southern Russia, a combination of high air temperature and humidity during almost the entire growing season of the apple tree leads to the development of a large number of pathogen generations, which requires regular treatments with shorter intervals between them [1]. Even now, in the years of epiphytoties of the disease, the use of drugs of chemical origin does not always provide high efficiency of protection against scab. It has been proved that modern chemical fungicides, as a rule, do not provide a complete suppression of phytopathogens, since under

* Corresponding author: biometod@vniimk.ru 
their action, micromycetes-saprotrophs sensitive to fungicides, which are competitors of pathogens, are eliminated from the biocenosis $[2,3]$. This situation can eventually lead to the emergence of resistance of $\mathrm{V}$. inaequalis to the main chemical groups of fungicides, pose a threat to the environment and cause phytosanitary destabilization of the entire agrocenosis of the apple tree.

To increase the stability of agrobiocenoses, domestic and foreign researchers are developing technologies for the restoration and increase of biological diversity [4]. One of the areas of research is the study of natural resources of useful microorganisms for the selection of promising biocontrol agents and the creation of polyfunctional environmentally friendly drugs. Among them, the most promising are microbiological, developed on the basis of living cultures of microorganisms and possessing a preventive and prolonged action [2, 5-7]. Biological products used as biofungicides consist of selected natural strains of microorganisms with pronounced biological activity. To search for effective control of phytopathogens, bacteria from the genera Bacillus, Pseudomonas, Serratia, Rhizobium, Streptomyces are most often studied [6, 8-10]. Bacillus strains of the genus Bacillus possess high antagonistic activity and serve as producers of biological substances: amino acids, amylo-, proteo- and lipolytic enzymes, as well as polypeptide antibiotics [8, 11]. Identified strains of bacteria B. pumilis, B. methyloprophics, Brevibacterum halotolerans, active against a fairly wide range of apple mycopathogens $[2,6]$. Based on the high antagonistic potential, growth rate and the possibility of cultivation under industrial conditions, fungi of the genus Trichoderma are widely used [12-14]. However, most of the drugs created in Russia are registered for use on cereals, vegetables, industrial crops [6], while for the control of apple diseases - only 5. In connection with the above, it is relevant to research to find new promising strains of microorganisms to control the pathogen apple scab, competitive with synthetic fungicides and related commercial preparations

Purpose of the study: to study the effectiveness of laboratory samples of microbiological preparations in the control of the causative agent of apple scab in a field experiment.

\section{Materials and methods}

The objects of research were laboratory samples of microbiological preparations from the collection of the Federal State Budgetary Scientific Institution VNIIMK. The tests were carried out on the basis of modern methodology [15] in 2016 and 2019 in field experiments in the Krasnodar region on the basis of the experimental farm of the FGBNU SKFNTsSVV: ZAO OPKh "Tsentralnoye". The stationary site was located in an industrial area of apple tree plantations. In 2016, tests were carried out on the Champion variety, highly susceptible to scab under the conditions of the region, planting in 2010 , tree height $1.5-2 \mathrm{~m}$, planting pattern $4.5 \times 1.2 \mathrm{~m}$. Treatments were carried out three times: at the stage of apple tree development : "About $50 \%$ of the variety-typical fruit size achieved"; "About $80 \%$ of the variety-typical size of the fruit has been achieved"; "About $90 \%$ of the variety-typical size of the fruit has been achieved." Laboratory samples of microbiopreparations were tested in the formulation "wettable powder" (SP) with a consumption rate of $0.15 \mathrm{~kg} / \mathrm{ha}$.

Experience scheme:

1. PK-1 Penicillium vermiculatum

2. XK-1 Chaetomium olivaceum

3. T-2 Trichoderma sp.

4. XK-3 Chaetomium sp. (Ketomium producer strain)

5. Fa-4-1 Bacillus sp.

6. Fa-4-2 Bacillus sp.

7. Sgrs-1 Pseudomonas sp. 
8. B-2 Bacillus sp.

9. B-12 Bacillus licheniformis

10. Standard: Delan, VG (700 g / $\mathrm{kg}$ dithianon) with a consumption rate of $0.6 \mathrm{~kg} / \mathrm{ha}$

11. Control - water treatment.

In 2019, trials were carried out on the variety Golden Delicious Reinders, medium susceptible to scab, planting in 2010, tree height $1.5-2 \mathrm{~m}$, planting pattern $4 \times 1.2 \mathrm{~m}$. The treatment was carried out at the apple stage "about $80 \%$ of the variety-typical size of the fruit was achieved".

Experience scheme:

1. PK-1 Penicillium vermiculatum

2. XK-1 Chaetomium olivaceum

3. Mixed sample RK-1 + XK-1 -1: 1 .

4. Mixed preparation RK-1 + HC-1 + B-12 Bacillus licheniformis - 1: 1: 1.

5. Standard: Buzzer, KS (500 g / 1 of fluazinam), with a consumption rate of $0.71 /$ ha.

6. Control - water treatment.

Working fluid consumption - at the rate of 10001 / ha, repeatability - three times.

\section{Results and discussion}

In 2016, the development of scab was characterized as tardive epiphytoty. Before using laboratory samples of microbiological preparations, the spread of scab on the leaves was $4.33 \%$, the intensity of the development of the disease was $2.30 \%$. The disease did not appear on the fruits of the treated variants. All tested samples significantly reduced the spread of scab, however, the difference between the variants was significant. According to the results of three treatments, laboratory samples of RK-1, XK-1 and T-2 were distinguished: they showed the best - in the range of 76.9-92.5\% - and the most stable protection efficiency, which approached the efficiency of the standard (Table 1).

Table 1. Efficiency of laboratory samples of microbiological preparations based on promising producer strains in the control of apple scab in the Krasnodar region, \%, 2019

\begin{tabular}{|c|c|c|c|c|c|c|c|c|c|}
\hline \multirow{3}{*}{$\begin{array}{c}\text { Experi- } \\
\text { ence } \\
\text { variant }\end{array}$} & \multicolumn{9}{|c|}{ Posting date } \\
\hline & \multicolumn{3}{|c|}{$\begin{array}{c}12.07,7 \text { th day after the } \\
1 \text { st treatment }\end{array}$} & \multicolumn{3}{|c|}{$\begin{array}{l}29.07,9 \text { th day after the } \\
\text { 2nd treatment }\end{array}$} & \multicolumn{3}{|c|}{$\begin{array}{l}\text { 10.08, 9th day after the } \\
\text { 3nd treatment }\end{array}$} \\
\hline & $\mathrm{P}, \%$ & $\mathrm{R}, \%$ & $\mathrm{BE}, \%$ & $\mathrm{P}, \%$ & $\mathrm{R}, \%$ & $\mathrm{BE}, \%$ & $\mathrm{P}, \%$ & $\mathrm{R}, \%$ & BE, $\%$ \\
\hline PK-1 & 7.35 & 3.68 & 90.4 & 10.00 & 5.73 & 87.0 & 13.50 & 7.50 & 83.7 \\
\hline XK-1 & 10.50 & 5.52 & 85.5 & 14.69 & 8.22 & 81.4 & 17.94 & 10.63 & 76.9 \\
\hline $\mathrm{T}-2$ & 6.00 & 2.86 & 92.5 & 12.45 & 7.08 & 84.0 & 17.38 & 10.47 & 77.3 \\
\hline XK-3 & 11.13 & 5.96 & 84.4 & 20.88 & 13.08 & 70.4 & 28.13 & 16.26 & 64.7 \\
\hline Fa-4-1 & 18.33 & 10.10 & 73.6 & 21.63 & 13.15 & 70.2 & 25.50 & 14.18 & 69.2 \\
\hline Fa-4-2 & 15.42 & 8.87 & 76.8 & 17.17 & 9.15 & $\begin{array}{l}79.3 \\
\end{array}$ & 20.75 & 12.60 & 72.7 \\
\hline Sgrs-1 & 14.75 & 8.70 & 77.2 & 19.63 & 8.98 & 79.7 & 23.50 & 14.51 & 68.5 \\
\hline B-2 & 21.83 & 12.07 & 68.4 & 28.62 & 16.23 & 63.3 & 36.25 & 24.40 & 47.1 \\
\hline B-12 & 26.96 & 15.42 & 59.6 & 35.75 & 25.35 & 42.6 & 46.25 & 30.40 & 34.10 \\
\hline $\begin{array}{l}\text { Zoomer, } \\
\text { SC, } \\
\text { standard }\end{array}$ & 5.50 & 2.95 & 92.2 & 6.00 & 3.39 & 92.3 & 6.67 & 3.26 & 92.9 \\
\hline Control & 65.00 & 38.20 & - & 75.00 & 44.20 & - & 77.32 & 46.10 & - \\
\hline $\operatorname{LSD}_{05}{ }^{*}$ & 2.74 & 2.11 & 2.33 & 3.04 & 2.39 & 2.67 & 3.08 & 2.44 & 2.92 \\
\hline
\end{tabular}


Legend: P,\% - disease spread; R,\% - the intensity of the development of the disease; $\mathrm{BE}, \%$ - biological efficiency.

Note: LSD - Least Significant Difference

The next group in terms of efficiency - from 64.7 to $84.4 \%$ - consisted of laboratory samples XK-3, Fa 4-1, Fa 4-2 and Sgrc-1. However, the effectiveness of these samples varied significantly in replication of the experiment. In laboratory samples B-2 and B-12, a level of effectiveness was obtained that was insufficient to contain epiphytotic forms, which include apple scab.

In 2019, before the tests, there was no conidial sporulation of scab on the leaves and fruits of the apple tree. On the 7 th day after treatment, scab on the leaves manifested itself in all variants of the experiment.

All variants with the use of laboratory samples of microbiological preparations were more effective in the control of scab, in comparison with the active substance of chemical origin of the contact action of fluazines (Table 2). The best efficiency was shown by the variant of using a laboratory sample of a mixed three-component preparation: based on two fungal and one bacterial producer strain - RK-1 + XK-1 + B-12. A significant difference was obtained between this variant and the variant of application based on one producer strain - PK-1, but the effectiveness of this laboratory sample exceeded the effectiveness of a chemical preparation. It should be noted that the action of laboratory samples of microbiological preparations proceeded under conditions of increasing conidial sporulation of scab: more than $5 \%$ of the leaves were infected on control trees within 7 days. On the 14th day after treatment, similar results were obtained. The best scab control was provided by the option of using a laboratory sample of a three-component mixed preparation RK-1 + XK-1 + B-12. The least effective scab was contained in the option of using sample RK-1, which, nevertheless, as well as according to the results of the first survey, exceeded the chemical standard in efficiency. The variant with a chemical fungicide gave way to all the variants of using laboratory samples of microbiological preparations. In the control, from 08.22 to 08.29 , the number of affected leaves doubled, the intensity of the development of the disease increased 3 times. The scab did not develop on the fruits of all variants, including control.

Table 2. Efficiency of laboratory samples of microbiological preparations based on promising producer strains in the control of apple scab in the Krasnodar region,\%, 2019

\begin{tabular}{|c|c|c|c|c|c|c|}
\hline \multirow{2}{*}{ Variant } & \multicolumn{6}{|c|}{ Posting date } \\
\cline { 2 - 7 } & \multicolumn{3}{|c|}{$\begin{array}{c}22.08,7 \text { th day after } \\
\text { treatment }\end{array}$} & \multicolumn{3}{c|}{$\begin{array}{c}29.08,14 \text { th day after } \\
\text { treatment }\end{array}$} \\
\cline { 2 - 7 } & $\mathrm{P}, \%$ & $\mathrm{R}, \%$ & $\mathrm{BE}, \%$ & $\mathrm{P}, \%$ & $\mathrm{R}, \%$ & $\mathrm{BE}, \%$ \\
\hline PK-1, CП & 1.78 & 0.62 & 75.3 & 4.33 & 2.07 & 72.6 \\
\hline XК-1, CП & 1.55 & 0.53 & 78.5 & 3.11 & 1.64 & 78.0 \\
\hline PК-1+ XК-1, CП & 1.44 & 0.47 & 81.1 & 4.11 & 1.96 & 74.4 \\
\hline PК-1+XK-1+ Б-12, CП & 1.33 & 0.38 & 84.9 & 2.67 & 1.27 & 83.0 \\
\hline Zommer, SC, standard & 2.67 & 0.87 & 65.9 & 7.33 & 3.51 & 53.6 \\
\hline Control & 5.75 & 2.50 & - & 12.25 & 7.66 & - \\
\hline LSD $^{*}{ }^{*}$ & $\mathbf{1 . 3 0}$ & $\mathbf{0 . 9 0}$ & $\mathbf{3 . 0 8}$ & $\mathbf{1 . 9 1}$ & $\mathbf{1 . 5 5}$ & $\mathbf{3 . 8 5}$ \\
\hline
\end{tabular}

\section{Conclusion}

Tests of laboratory samples of microbiological preparations based on promising producer strains in a preparative form of a wettable powder (SP) with a consumption rate of $0.15 \mathrm{~kg} /$ 
ha against apple scab showed that they all had a protective effect against the pathogen. In 2016, out of 9 laboratory samples of microbiological preparations on a highly susceptible cultivar under conditions of disease epiphytotics. In three consecutive treatments, samples RK-1, XK-1 and T-2 provided the highest, approaching the level of chemical fungicide, as well as the most stable efficiency. In 2019, all variants with the use of laboratory samples of microbiological preparations were more effective in controlling scab, in comparison with the active substance of chemical origin. The best scab control was provided by the option of using a laboratory sample of a three-component mixed preparation RK-1 + XK-1 + B-12. The isolated laboratory samples are promising for further research on the creation of effective microbiological preparations.

\section{References}

1. J.-M. Legave, G. Malagi, A. Yaacoubi, M. Bonhomme, Front. Plant Sci., 6, 1054 (2015) http://doi.org/10.3389/fpls.2015.01054

2. I.I. Novikov. Technol. Techn. Means Mechan. Prod. Crop Livest. Prod., 2 (99), 183-194 (2019) https://doi.org/10.24411/0131-5226-2019-10162

3. G. Taj, P.D. Meena, P. Giri, D. Pandey, A. Kumar, A. Kumar, J. Oilseed Bras., 6, 213239 (2015) https://www.researchgate.net/publication/306380727

4. V.M. Chapla, M.L. Zeraik, V.F. Ximenes, L.M. Zanardi, M.N. Lopes, A.J. Cavalheiro, D.H.S. Silva, M.C.M. Young, L.M. da Fonseca, V.S. Bolzani, A.R. Araújo. Molecules, 19, 6597-6608 (2014) http://doi.org/10.3390/molecules19056597

5. L.V. Maslienko, A.Kh. Voronkova, L.A. Datsenko. Proceedings of the Kuban State Agrarian University, 78, 91-98 (2019), http://doi.org/10.21515/1999-1703-78-91-98

6. V.A. Pavlyushin, I.I. Novikova, I. V. Boykova. Agric. biol., 55(3), 421-438 (2020) http://doi.org/10.15389/agrobiology.2020.3.421eng

7. F.M. Freimoser, M.P. Rueda-Mejia, B. Tilocca, Q. Migheli. World J Microbiol Biotech., 35, 154-173 (2019) http://doi.org/10.1007/s11274-019-2728-4

8. A. Singh, M. Shahid, M. Srivastava, S. Pandey, A. Sharma, V. Kumar, Virol. Mycol., 3(1), 1000127 (2014) http://dx.doi.org/10.4172/2161-0517.1000127

9. R.F. Doornbos, L.C. van Loon, P.A.H.M. Bakker, Agron. Sustain. Dev., 32, 227-243. (2012) http://doi.org/10.1007/s13593-011-0028-y

10. I. Hemissi, Y. Mabrouk, N. Abdi. M. Bouraoui, M. Saidi, B. Sifi., African J. Microbiol. Res., 24(5), 4080-4090 (2011) http://doi.org/10.1007/978-3-319-59174-2 7

11. A. Kita, S. Chandel, M. Kumar, V.K. Meena, Int. J. Curr. Microbiol. Appl. Sci., 8, 2474-2480 (2019) http://doi.org/10.20546/ijcmas.2019.812.291

12. M. Ruocco, S. Lanzuise, N. Lombardi, S. Woo, F. Vinale, R. Marra, R. Varlese, G. Manganiello, A. Pascale, V. Scala, D. Turra, F. Scala, M. Lorito, Mol. Plant Microbe Interact., 28, 167-179 (2015)

13. K. Pastirčáková. Biological lett., 54 (1), 21-35 (2019) http://doi.org/10.2478/biolet2019-0003

14. P. Martínez-Álvarez, F.M. Alves-Santos, J.J. Diez, S. Fennica, 46(3), 303-316 (2012) https://doi.org/10.14214/sf.42

15. Ch. Perrings, A. K. Duraiappah, A. Larigauderie, H. Mooney, Sci., 331, 1139-1140 (2011) https://doi.org/10.1126/science. 1202400 